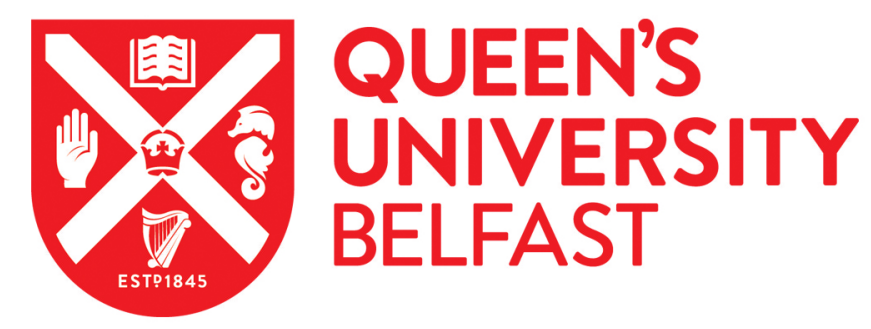

\title{
Feminists redraw public and private spheres: Abortion, vulnerability, and the affective campaign to repeal the eighth amendment
}

Fischer, C. (2020). Feminists redraw public and private spheres: Abortion, vulnerability, and the affective campaign to repeal the eighth amendment. Signs, 45(4), 985-1010. https://doi.org/10.1086/707999

\section{Published in:}

Signs

\section{Document Version:}

Peer reviewed version

Queen's University Belfast - Research Portal:

Link to publication record in Queen's University Belfast Research Portal

\section{Publisher rights}

(C) 2020 by The University of Chicago. All rights reserved.

This work is made available online in accordance with the publisher's policies. Please refer to any applicable terms of use of the publisher.

\section{General rights}

Copyright for the publications made accessible via the Queen's University Belfast Research Portal is retained by the author(s) and / or other copyright owners and it is a condition of accessing these publications that users recognise and abide by the legal requirements associated with these rights.

Take down policy

The Research Portal is Queen's institutional repository that provides access to Queen's research output. Every effort has been made to ensure that content in the Research Portal does not infringe any person's rights, or applicable UK laws. If you discover content in the Research Portal that you believe breaches copyright or violates any law, please contact openaccess@qub.ac.uk. 


\section{Feminists Redraw Public and Private Spheres: Abortion, Vulnerability, and the Affective Campaign to Repeal the $8^{\text {th }}$ Amendment}

On $25^{\text {th }}$ May 2018, Irish citizens voted in a referendum to repeal an amendment to the constitution to allow for reform of Ireland's prohibitive law on abortion. In this article, I examine parts of the Irish repeal campaign, focusing particularly on the interplay between "public" and "private" in the context of a public, feminist campaign that sought specific changes to public policy on matters that have traditionally been conceived of as private. Added to this, I explore some affective elements of the campaign, including the historic shaming it rejected through visibility and exposure, and the emotive testimony it relied on. The article thus highlights the centrality of feeling to this particular feminist campaign, pointing to emotion as shared, political phenomenon that cuts across public and private spheres to motivate political change. Moreover, it develops a largely undertheorized aspect of Judith Butler's work, establishing the affective dimension of vulnerability in the context of feminist campaigning. My analysis thus delineates the role of public and private in the exposure entailed by affective vulnerability as a means of nonviolent, feminist resistance, and points to women's testimony and the affective revealing of trauma as a means of making the ideas of 'public' and 'private' tangible and translatable into grassroots, feminist activism.

On $25^{\text {th }}$ May 2018, Irish citizens voted in a referendum to repeal an amendment to the constitution to allow for reform of Ireland's notoriously strict and prohibitive law on abortion. ${ }^{1}$ The vote paved the way for implementation of a much more liberal abortion regime, ${ }^{2}$ and was brought about by the concerted efforts of volunteers and advocates right across the country as part of a vast and effective, public, feminist campaign. The exceedingly positive result - carried by $66.4 \%$ in favor of repeal ${ }^{3}$ - came as a shock, even to the most optimistic of political analysts and campaigners. It was widely anticipated that the pro-choice "win," should it materialize at all, was going to be a narrow one, and would roughly fall along urban/rural lines. In the end, there were some differences in voting behavior, ${ }^{4}$ but the predicted, stark demographic divisions did not transpire, except that the older cohort (65 years plus) formed the only segment of the Irish electorate to buck the trend by largely supporting a 'no' vote. ${ }^{5}$

\footnotetext{
${ }^{1}$ This article is dedicated to the many, many people in Ireland who have worked tirelessly to bring about a more humane and caring abortion regime in Ireland, especially to those who have bravely shared their personal experiences of the harms inflicted by the $8^{\text {th }}$ Amendment.

${ }^{2}$ A draft of this was already available to the public at the time of voting, and was largely based on the recommendations of a Citizens' Assembly and a parliamentary committee examining the assembly's findings - see Government of Ireland, "General Scheme Of A Bill to Regulate Termination of Pregnancy,” March 28, 2018, https://health.gov.ie/wp-content/uploads/2018/03/General-Scheme-forPublication.pdf. Unfortunately there are still shortcomings in the now adopted abortion legislation, such as a three day wait period since initial doctor visit, and a lack of clarity on how fatal fetal abnormality is to be interpreted, with the result that women from Ireland will continue to travel to seek abortion access elsewhere.

${ }^{3}$ RTÉ, “Referendum 2018," RTÉ News, 2018, https://www.rte.ie/news/eighth-amendment/results/.

${ }^{4}$ Donegal, a largely rural constituency, was the only constituency to (narrowly) vote no - see Joyce Fegan, "Donegal the Only Constituency to Vote No," The Irish Examiner, May 28, 2018.

5 Ian McShane, "Thirty-Sixth Amendment to the Constitution Exit Poll, 25th May, 2018," 2018, https://static.rasset.ie/documents/news/2018/05/rte-exit-poll-final-11pm.pdf.
} 
The overwhelming endorsement of a more permissive abortion system in Ireland, especially by younger people,${ }^{6}$ has much to say about changes in Irish culture on matters of reproduction, sexuality, and gender in recent years - matters on which Ireland carries a rather dismal track record of patriarchal, Church/State-sponsored conservatism. The abortion referendum indicates how feminist movements may affectively act as drivers of socio-political change. Indeed, the impact of grassroots, feminist campaigning on one of the most politically contentious and gendered issues which Irish politicians have been loath to approach, ${ }^{7}$ never mind radically redress - is bound to be instructive for feminists interested in bringing about serious political transformation elsewhere. ${ }^{8}$ Moreover, there are distinct insights that can be drawn from this context on the interplay of emotion and the public/private distinction that may also be instructive in other settings, and that allow us to reconceptualize important feminist theoretical ideas.

In what follows, I will examine parts of the Irish repeal campaign, ${ }^{9}$ focusing particularly on the interplay between "public" and "private" in the context of a "public," feminist campaign that sought specific changes to "public" policy on matters that have traditionally been conceived of as "private." I will be focusing, specifically, on some affective elements of the campaign, including the historic shaming it rejected through visibility and exposure. As such, my discussion will explore how shame may be resisted or undercut, not with anything as straight-forward as pride (which shame theorists often warn against as an easy, but misleading substitution), but rather through the deployment of visibility. It will also explore the emotive testimony relied upon during the repeal campaign. The article will thus highlight the centrality of feeling to this particular feminist campaign, pointing to emotion as shared, political phenomenon that cuts across public and private spheres to motivate political change. Moreover, it will develop an aspect of Judith Butler's idea of vulnerability that is, so far, largely missing in Butler's thought, establishing the affective dimension of vulnerability in the context of feminist campaigning. ${ }^{10} \mathrm{My}$ analysis will also delineate the role of public and private in the exposure entailed by affective vulnerability, as I term it, as a means of nonviolent, feminist resistance. Finally, I will point to women's testimony and the affective revealing of trauma as a means of making the ideas of 'public' and 'private' tangible and translatable into grassroots, feminist activism. As such, the article will contribute to affect studies,

\footnotetext{
${ }^{6}$ According to the exit poll conducted for the public broadcaster, $87.6 \%$ of $18-24$ year olds voted in favor of repeal - Ibid.

${ }^{7}$ Successive Irish legislatures have been reluctant to redress the shortcomings in Ireland's abortion regime (other than to attempt to further restrict abortion access). This has been evinced by a more than twenty year hiatus in legislating for the X case - see Fiona De Londras and Máiréad Enright, Repealing the 8th: Reforming Irish Abortion Law (Bristol: Policy Press, 2018), 58.

${ }^{8}$ While each political context is of course unique, there may be particular aspects of feminist campaigning in one context that may be useful to another.

${ }^{9}$ The reason I'm referring here to the repeal campaign, rather than to the official Together for Yes campaign body, is to acknowledge that the struggle for abortion rights in Ireland is one that long predates the formal Together for Yes campaign of 2018. In the rest of this essay, I will be sure to delineate between the Together for Yes campaign and other reproductive rights activism that either predates this or did not necessarily ascribe to Together for Yes strategy.

${ }^{10}$ In Frames of War, Butler only discusses affect in terms of affective "responsiveness," and, in Notes Toward a Performative Theory of Assembly, does not seem to afford affect a place in her discussion of vulnerability and resistance. In what follows, I will be redressing this undertheorization of affectivity in the context of exposure, women's testimony, and public/private delineations.
} 
feminist canonical work in the politics of emotion, ${ }^{11}$ and shame theory, ${ }^{12}$ as well as to the literature on reproduction and abortion in Ireland, ${ }^{13}$ and to feminist work on the ideas of "public" and "private" in political theory. ${ }^{14}$

\section{The Public/Private Dichotomy in an Irish Context}

Feminist political theorists have long criticized liberalism's division between a public, political sphere and a private sphere, the latter assumed to be non-political and falling outside of legal governance. Carole Pateman, for instance, has characterized this classic, liberal conception of the public/private dichotomy as an onerous feature of social contract theories that omit the original, "sexual contract" that underpins patriarchal control and prohibits women from entering civil society as equals. ${ }^{15}$ Indeed, for Pateman, contra liberal expositions, men have had the privilege of straddling both public and private spheres (as public individuals and as heads of households), ${ }^{16}$ while women have traditionally been relegated to the private sphere, which has been deemed more befitting of them. The purpose of the stark division between public and private, then, is not, as set out in liberal theory, to establish a political sphere and a sphere free from politics and the law, but rather to establish and maintain patriarchal control via the family, thereby resulting in the limiting of women's equality in both public and private spheres. Similar arguments have been developed by Susan Moller Okin, who notes that the public/private dichotomy is "a misleading construct, which obscures the cyclical pattern of inequalities between men and women." ${ }^{17}$ Feminists have also pointed to the fact that the state and its instruments of law already intervene and regulate typically "private" affairs, such as marriage contracts, and, in fact, should intervene on egregious, gendered issues, such as domestic violence. In feminist political terms, state mechanisms of law and order, and the principles of justice underpinning same, should, therefore, be extended to the private sphere. ${ }^{18}$

The reasons for this have been obvious at least since the second wave feminist articulation of 'the private being political', as inequality and harms within the private sphere must be mitigated by political and legal means. Moreover, such inequality and harms are not necessarily isolatable within a particular sphere, as gendered injustices

\footnotetext{
${ }^{11}$ For an overview of feminist work on emotions and the contemporary "turn to affect" as it relates to this, see Clara Fischer, "Feminist Philosophy, Pragmatism, and the 'Turn to Affect': A Genealogical Critique," Hypatia: A Journal of Feminist Philosophy 31, no. 4 (2016): 810-26.

${ }^{12}$ See the recent special issue of Hypatia on this, Clara Fischer, ed., "Gender and the Politics of Shame," Hypatia: A Journal of Feminist Philosophy [Special Issue] 33, no. 3 (2018). As well as Luna Dolezal, The Body and Shame: Phenomenology, Feminism, and the Socially Shaped Body (London: Lexington Books, 2015).

${ }^{13}$ See, for instance, De Londras and Enright, Repealing the 8th: Reforming Irish Abortion Law. Ursula Barry, "What Do We Mean by Bodily Autonomy? And What Does Bodily Autonomy Mean for Women in Particular?," in Autonomy (Cork: New Binary Press, 2018), 180-92. Ivana Bacik, "A Feminist Review of the Law on Abortion," in Irish Feminisms: Past, Present and Future, ed. Clara Fischer and Mary McAuliffe (Dublin: Arlen House/Syracuse University Press, 2015), 147-68.

${ }^{14}$ Prominent examples of this include Carole Pateman, The Sexual Contract (Cambridge: Polity Press, 1988) and Okin (1989).

${ }^{15}$ Carole Pateman, The Sexual Contract (Cambridge: Polity Press, 1988).

${ }^{16}$ Carole Pateman, The Disorder of Women: Democracy, Feminism, and Political Theory (Stanford: Stanford University Press, 1989), p. 183.

${ }^{17}$ Susan Moller Okin, Justice, Gender and the Family (New York: Basic Books, 1989), 111.

18 Ibid.
} 
may reach across spheres and reinforce each other in complex ways. Women's historic relegation to the private sphere has also limited our influence on public policies and mechanisms that regulate the private sphere, thereby maintaining and fostering inequality and harms within the family. While Okin holds that there is value to be had in reasonably delineating public and private spheres, or, indeed, in privacy more generally, she notes that the private sphere is itself "created by political decisions." 19 Hence, for her, the question is not whether the private sphere remains untainted by the political and legal intervention allegedly solely typical of the public sphere, but, rather, how such intervention takes place, that is, to which ends it is put (such as, historically, the promotion of the patriarchal, nuclear family, or the establishment of men as heads of households).

Almost thirty years later, the work of Okin, Pateman, and similar critics of liberalism's public/private dichotomy, is still relevant, despite significant attitudinal changes related to the family and transformed gendered practices, including women's increased participation in the formal labor force - changes that have had a marked impact on both public and private spheres. In Ireland this has also been borne out by a recent Marriage Equality referendum, which, dramatically, formed a first in electoral history by legalizing same-sex marriage via popular vote, thereby politically instituting an alternative to the patriarchal family model. ${ }^{20}$ Given the opportunity afforded by the present special issue on public feminisms, I will be focusing here on another recent Irish referendum to bring about serious reform to a historically conservative social policy context, on perhaps the most fractious, gendered political issue, abortion, by revisiting assumptions about "public" and "private." The topic is not just a timely one, given the recent vote, but one that amply illustrates the continued purchase of analyses that problematize the public/private dichotomy and examine how, exactly, public policy regulates gendered matters deemed to be of a private nature.

The Irish case is particularly interesting in terms of an assessment of the demarcation of "public" and "private," given the rather sorry and protracted history of state intervention in domestic affairs that for many decades fundamentally and radically circumscribed family formation and relational bonds, and sexual and reproductive practices. Throughout the twentieth century, such intervention was largely shaped by a nationalist, postcolonial imaginary, and was undertaken by the State together with the religious orders, driven by a religio-political ideology that rested on gendered notions of sexualized purity and the nation's presumed superior - and, notably, gendered - virtue..$^{21}$ It included the forced separation and the mass-institutionalization of women and children; ${ }^{22}$ the withholding of information, especially on reproduction

\footnotetext{
19 Ibid, 111.

${ }^{20}$ There were important overlaps between the Marriage Equality referendum and the referendum to repeal the $8^{\text {th }}$ Amendment - in terms of campaigning, argumentation, and political mobilisation, and important lessons could be drawn from the former campaign. Taken together, these referenda indicate important changes in Ireland on matters of gender, sexuality, reproduction, and the family, with, as I will outline below distinct implications for how and where the line between public and private should be drawn.

${ }^{21}$ Clara Fischer, "Gender, Nation, and the Politics of Shame: Magdalen Laundries and the Institutionalisation of Feminine Transgression in Modern Ireland," Signs: Journal of Women in Culture and Society 41, no. 4 (2016): 821-43.

${ }^{22}$ Institutionalisation in Ireland was wide-reaching, and peaked in the 1950s with one in 100 per capita institutionalised, see Eoin O'Sullivan and Ian O’Donnell, “Explaining Coercive Confinement: Why
} 
and sexuality; a prohibition of contraception and, of course, abortion; ${ }^{23}$ and the use of questionable, often brutal medical practices, such as symphysiotomy. ${ }^{24}$

Modern Ireland thus witnessed the widespread deployment of several highly invasive church-state mechanisms to promote the nuclear family, to regulate sexuality and reproduction, and to control non-normative families and relationships (especially pregnancy out of wedlock). Such mechanisms were disciplining in so far as they constructed and accordingly punished women and children deemed to be transgressive of a national identity premised on superior purity. Not only, then, did the state, together with the Church, intervene in the private sphere, but it did so in drastic and cruel ways: through the diminishment of women's bodily autonomy and agency via physical removal and incarceration in institutions such as Magdalen Laundries, Mother and Baby Homes, and County Homes (Work Houses); denial of reproductive rights, choice, or consent; ${ }^{25}$ and illegal adoption and the severing of familial bonds. ${ }^{26}$

Intervention in the private sphere in Ireland was thus systematic and far-reaching, and served the purpose of consolidating patriarchal power through family, church, and state alike, as part of a wider conservative mobilization against feminism and women post-Independence. Intervention in the private sphere, in women's very materiality, moreover, excused and hid male, sexual transgression - the consequences of pregnancy out of wedlock were, after all, overwhelmingly borne by shamed, "fallen" women - instituted patriarchal control over women's bodies, including over family planning, and simultaneously cemented women's role in the private sphere with restricted access to the public sphere. The Irish context thus clearly highlights Okin's point that discussions on public and private spheres must start from the position that state interventions in domestic matters have already been happening, and that we must examine how, and to what end.

Since the heavily interventionist social policies and practices characterizing the newly independent Ireland unfolded as part of a wider restriction of women from the public

Was the Past Such a Different Place?," in Coercive Confinement in Ireland, ed. Eoin O'Sullivan and Ian O’Donnell (Manchester: Manchester University Press, 2012), 250-94. Notably, institutionalisation was also gendered and driven by a particular postcolonial conception of Ireland as a nation of superior (sexual) virtue - see Fischer, "Gender, Nation, and the Politics of Shame: Magdalen Laundries and the Institutionalisation of Feminine Transgression in Modern Ireland" and Clara Fischer, "Revealing Ireland's 'Proper' Heart: Apology, Shame, Nation," Hypatia: A Journal of Feminist Philosophy 32, no. 4 (2017): 751-67.

${ }^{23}$ See Clara Fischer, "Abortion and Reproduction in Ireland: Shame, Nation-Building, and the Affective Politics of Place," Feminist Review 122, no. 1 (2019).

${ }^{24}$ Máiréad Enright, “"No. I Won’t Go Back': National Time, Trauma and Legacies of Symphysiotomy in Ireland," in Law and Time, ed. Sian Beynon-Jones and Emily Grabham (Routledge, 2018).

25 The constitutional protection of the "unborn", which will be discussed further below, also impacted upon women's right to refuse medical treatment and give consent. The Irish health service's consent policy thus states that while normally a woman has the right to refuse medical treatment, "because of the constitutional provisions on the right to life of the "unborn", there is significant legal uncertainty regarding the extent of a pregnant woman's right to refuse treatment in circumstances in which the refusal would put the life of a viable foetus at serious risk. In such circumstances, legal advice should be sought" - Health Service Executive, "National Consent Policy," 2013, p. 41.

${ }^{26}$ Important work has been done over the years by adopted people and their representative organizations to highlight the flaws and illegalities in Ireland's adoption system, which frequently underpinned gendered institutionalization - see www.adoptionrightsalliance.com 
sphere, opportunities for women to challenge such policies were limited..$^{27}$ The upshot of this was that women in Ireland have lived with such policies (or in cases of reform, such policies' legacies), for many decades, with the harms of illegal adoption, massinstitutionalization, symphysiotomy, inter alia, only lately, publicly recognized as harms at all - hence the very recent and ongoing investigations into various institutions and dubious Church-state social policy measures and practices. ${ }^{28}$ This also holds true for the historic prohibition on abortion in Ireland, which received a belated boost with a constitutional copper-fastening of the ban in 1983, largely in response to Irish conservatives' fears of social, liberal encroachment posed by Roe v. Wade in the U.S. and McGee v. Attorney General in Ireland. ${ }^{29}$

Interestingly, from the point of view of "public" and "private" demarcations, the McGee case resulted in the legalization of importation of contraception for married couples on the basis of the constitutional right to privacy, the Supreme Court ruling that marital privacy was implied within the Irish Constitution. ${ }^{30}$ Hence, despite the protracted history of the Irish state's drastic intervention in the private sphere, the idea of "privacy," and the constitutional right to privacy underpinning same, have been invoked to challenge and limit such intervention. As feminist legal scholars De Londras and Enright point out, though, McGee still held that abortion access did not fall under the right to privacy. ${ }^{31}$ Moreover, privacy is "not an unlimited right," but one which the Irish state may interfere with on the basis of protecting others' rights or the common good, although "marital privacy is to be "enjoyed with possibly the rarest of exceptions'." ${ }^{32}$ More generally, "privacy" has been used both in Irish domestic law and in international human rights law to counter restrictive laws governing reproduction and sexuality, and to seek clarification around access to services and legal remedy. ${ }^{33}$

Given these complexities of the public/private dichotomy, which in Ireland unfolds against a backdrop of severe intervention in the private sphere by a Church-State nexus that dates back at least to the foundation of the Irish state itself, what are we to make of the public and the private in this context? What can be said thus far, in agreement with Okin, Pateman, and similar second wave critics of traditional liberal conceptualizations of "public" and "private" is that contra the idea of the private sphere being an apolitical realm, in Ireland the domestic sphere is a highly politicized entity, which has been subject to extreme, interventionist policies and practices throughout the twentieth century and reaching into the present. Such interventions have been gendered, classed, and racialized, ${ }^{34}$ and stem from the normative, political

\footnotetext{
${ }^{27}$ I do not believe that political change only comes about through the public sphere, however, public policies made largely without women have not served women in Ireland well.

${ }^{28}$ See, for instance, the current investigation into Mother and Baby Homes - "Commission of Investigation (Mother and Baby Homes and Certain Related Matters)" (Dublin, 2015), http://www.dcya.gov.ie/documents/Mother_and_Baby_Homes/20150109DraftOrderCommofInvestigat ion.pdf.

${ }^{29}$ Bacik, "A Feminist Review of the Law on Abortion", p. 152.

${ }^{30}$ Ibid.

${ }^{31}$ De Londras and Enright, Repealing the 8th: Reforming Irish Abortion Law, 43.

${ }^{32}$ Ibid.

${ }^{33}$ Ibid, 44.

${ }^{34}$ The racialized dimension of this has been increasingly acknowledged, thanks to the work of survivors of institutions, such as Christine Buckley, and the advocacy group Mixed Race Irish. Children of interracial ancestry (often with African fathers) were sometimes institutionalized on the
} 
institutionalization of a particular Irish post-colonial identity in a newly independent, patriarchal nation-state.

That said, the public realm - of laws, courts, and policies - has also been used to stem patriarchal intervention in the private sphere on the basis of the protection of (marital) privacy, thereby achieving what may be interpreted as feminist ends. ${ }^{35}$ This means, following Nancy Fraser, not that public and private cannot or should not be delineated, but rather that the work of feminist politics lies in ascertaining where, exactly, that "line between public and private" should be drawn through the countering of patriarchal structures historically tasked with doing so. ${ }^{36}$ In what follows, I will be arguing that the recent repeal campaign in Ireland can be read precisely as such an effort to redraw the boundary of public and private realms, as it explicitly utilized arguments problematizing the relationship between public and private in the context of abortion law reform.

\section{Abortion Law Reform and the Role of Public/Private Demarcations in the Repeal Campaign}

As noted, Ireland's abortion ban received an added boost with a 1983 referendum designed to stave off what conservatives viewed as a potential tidal wave of social policy liberalization. The referendum resulted in the insertion of what is commonly known as the $8^{\text {th }}$ Amendment to the Constitution, or Article 40.3.3, which stipulated that the "state acknowledges the right to life of the unborn and, with due regard to the equal right to the life of the mother, guarantees in its laws to respect, and, as far as practicable, by its laws to defend and vindicate that right." ${ }^{37}$ As such, the $8^{\text {th }}$ Amendment gave a constitutional protection to the right to life of the "unborn" and equated this to the right to life of a woman. This amendment, as feminists at the time pointed out, pitted women's lives against fetuses' lives, and - since getting or facilitating an abortion could carry a potential 14-year prison term - frequently resulted in the effective prioritization of fetuses' lives over women's lives. ${ }^{38}$ Moreover, the legal emphasis on life, rather than health, stopped doctors from intervening "merely" to protect women's health in times of medical crisis, and required them to wait for the presence of life-threatening danger instead. ${ }^{39}$ The abortion ban in Ireland was thus almost complete, with abortion permissible only in cases where there was a "real and substantial" risk to a woman's life - this, latterly, also extending to risk to life by way of suicide. ${ }^{40}$ In practice, though, even such

\footnotetext{
basis of race and encountered particular, racialized abuse in the institutions - see Kitty Holland, "Mixed Race Irish: 'We Were the Dust to Be Swept Away," The Irish Times, July 18, 2015.

${ }^{35}$ I say "may be interpreted" as this can still be seen as a conservative argument for privacy based on the institution of marriage, rather, than, say, on women's bodily autonomy.

${ }^{36}$ Nancy Fraser, Justice Interruptus: Critical Reflections on the "Postsocialist" Condition (London: Routledge, 1997), 115.

${ }^{37}$ Constitution of Ireland - Bunreacht na hÉireann (2015).

${ }^{38}$ Although I will be speaking, in this article, of women in relation to the abortion ban, simply to highlight continuity with the historic treatment of women by the state, it is important to note that also some trans* people are and have been affected by Ireland's abortion regime.

${ }^{39}$ As one person cited in Amnesty International's report on the need for abortion law reform in Ireland succinctly put it: "for a doctor to say 'you are not dying enough yet' ... it is barbaric" - Alison Begas, Chief Executive of Dublin Well Woman, cited in Amnesty International, "She Is Not a Criminal: The Impact of Ireland's Abortion Law," 2015, http://www.amnestyusa.org/pdfs/Ireland_She_Is_Not_A_Criminal.pdf, p. 32.

${ }^{40}$ This was supposed to have been provided for by the Protection of Life During Pregnancy Act 2013, itself designed to give effect to the $1992 \mathrm{X}$ Case ruling. This latter case raised the question of
} 
limited abortion provision on the basis of risk to a woman's life was not guaranteed, and, as borne out by women's experiences, was largely arbitrary. ${ }^{41}$

Unsurprisingly, this legal regime, with its distinction between a woman's health and her life, the reduction of her life to a fetus's life, and the criminalization of abortion with a hefty prison sentence, led to several highly publicized tragedies. The most widely known of these, the death of Savita Halappanavar, did much to galvanize public opinion for the need for change. ${ }^{42}$ On $21^{\text {st }}$ October 2012, Savita Halappanavar was already undergoing a miscarriage when she was admitted to Galway University Hospital, but was repeatedly denied a termination on the grounds that there was a fetal heartbeat. She eventually developed septicemia and died seven days later. ${ }^{43}$ Her death highlighted the dangers the $8^{\text {th }}$ Amendment posed to all pregnant women, and the stark consequences of a system that in practice mandated the elevation of a fetus's life, even when this was already being lost, over and above a woman's life.

Following this tragic case, and on foot of many years of feminist activism, and increased pressure from international human rights bodies (including a recent ruling by the European Court of Human Rights, the Case of A, B, and C v Ireland 2010), and formal political processes, such as a deliberative Citizen's Assembly and the establishment of an Oireachtas (parliamentary) committee on the $8^{\text {th }}$ Amendment to examine the assembly's recommendations, a referendum was finally called by government in January 2018, with the vote to take place in May. A large-scale, public campaign to support the repeal of the $8^{\text {th }}$ Amendment was coordinated by a collective campaign body, Together for Yes, which represented over 70 organizations and civil society groups in Ireland, brought together by the National Women's Council (the umbrella organization for women's organizations in Ireland), the Abortion Rights Campaign, and the Coalition to Repeal the $8^{\text {th }}$ Amendment (the latter two groupings having been active on abortion rights for many years). Moreover, Together for Yes was supported by a plethora of volunteers, some of them more tightly affiliated with the formal campaign body than others, and were broadly scattered all over the country and abroad via the Irish diaspora and their supporters. They were engaged in a variety of tasks, including fundraising, canvassing, research, leafleting, media work, and maintaining the general logistical machinery required by a national, grassroots, feminist campaign. Together for Yes was officially launched on $22^{\text {nd }}$ March 2018, with the referendum date set for just two months later.

The intervening period was one of frantic, creative, feminist activity: books were published to raise funds and to inform policy; ${ }^{44}$ social media accounts were created to announce campaign details and to give voice to women's experiences; events were held to raise funds and to allow people to debate the issues; canvassing teams covered

suicidality in the context of an underage rape victim wanting to access abortion services in the UK. She was stopped from travelling, but this was later lifted on the basis of X's suicidality - see Protection of Life During Pregnancy Act 2013, 2013, http://www.irishstatutebook.ie/eli/2013/act/35/enacted/en/pdf. And Lisa Smyth, Abortion and Nation (New York: Routledge, 2005).

${ }^{41}$ See, for example, the cases of Ms. Y and Ms. Z discussed in Fischer, "Abortion and Reproduction in Ireland: Shame, Nation-Building, and the Affective Politics of Place."

${ }^{42}$ Kitty Holland, "How the Death of Savita Halappanavar Revolutionised Ireland," The Irish Times, May 28, 2018.

${ }^{43}$ Ibid.

${ }^{44}$ See De Londras and Enright, Repealing the 8th: Reforming Irish Abortion Law. And Kathy D'Arcy, ed., Autonomy (Cork: New Binary Press, 2018). 
vast terrain by knocking on people's doors and leafleting train stations and sporting events; spokespeople appeared on the airwaves and in print media; a headquarter was arranged to supply literature and other campaign materials; symbols, such as badges and the black and white Repeal jumpers, were produced and reproduced for distribution; policymakers were lobbied and briefed; and the 'no' side's misleading "information" and often sexist, disrespectful arguments were widely and consistently countered.

The 'yes' side focused strongly on the concrete harms endured by women in Ireland because of the $8^{\text {th }}$ Amendment, rather than on abstract questions, such as 'when does life begin,' as such questions have tended to obscure, or even erase, women and women's experiences. Moreover, such harms, resulting from Ireland's abortion ban, were explicitly placed in the context of the need for a renegotiation of public and private, with hitherto "private" suffering portrayed as requiring "public" intervention. This was most obviously captured in Together for Yes's slogan of "sometimes a private matter needs public support" (Fig. 1), which seemed to echo the second wave feminist credo that "the private is political." The statement was widely dispersed on posters erected all over the country, and called on members of the public to show their public support by voting for reform on what is or should be a private matter.

Arguments raised throughout the campaign and featured in the Together for Yes canvassing literature thus portrayed women's reproductive lives, and their potential need for abortion access, as requiring privacy and therefore needing to be protected from public intervention. One Together for Yes leaflet (Fig. 2), for instance, listed the implications of a 'yes' and 'no' vote in the following terms: under 'yes' it stated that "life is complicated and every pregnancy is different - vote yes to allow a woman to make important decisions about her own life and family"; under 'no' it said that "voting no means interfering with a woman's personal and private decisions about her life and family." The denial of abortion access to women was thus presented as a public intervention in women's private sphere, as women, in consultation with their doctors, should be free to make decisions about their reproductive lives themselves, including on whether they should have terminations. ${ }^{45}$ Hence, the 'yes' side called into question what should fall under "public" and "private" by providing a reading of the abortion ban as an undue interference in women's private decision-making. Nonetheless, in order to protect such privacy, and the freedom to make said personal decisions, public intervention - by way of the upcoming vote - was now required to allow for legal reform and thereby the granting of private decision-making to women.

To be sure, there are two different public entities being referenced here: on the one hand there is a historically patriarchal Church-supported state that has, for decades, followed a pattern of highly interventionist policy and practice in the private sphere by tightly controlling sexuality, reproduction, and family planning; on the other hand there is a general public with the chance to redress this arbitrary power of the state over women's reproductive lives, at least on the question of abortion law reform. By appealing to members of the public to support a 'yes' vote, campaigners thus highlighted the politicized nature of the private sphere in Ireland while advancing arguments for the protection of privacy to allow women to make decisions for

\footnotetext{
${ }^{45}$ This was also repeatedly reiterated by Together for Yes spokespeople - see Cormac McQuinn, “'Together For Yes' Group Deny 'No' Campaigners Have Stolen a March in Poster War,” The Irish Independent, 2018.
} 
themselves. The 'yes' side thereby called attention to what has long been a sad, but nonetheless prominent feature of social policymaking in Ireland: the diminishment of women's agency. The frequent, if sometimes indirect, references to this - for instance, through poster slogans such as "trust women" (Fig. 3), or the long-known protest chant "not the church, not the state, women must decide their fate" - presented women as being subject to a paternalistic state that infringed their decision-making capacities in the most intimate of matters concerning their own bodies and reproductive health.

\section{Emotion, Women's Testimony, and Public/Private Demarcations}

As I have argued elsewhere, what legitimated the severe intervention in the private sphere in an Irish context, was the deployment of shame and the construction of women's bodies - and their assumed capacity for sexual transgression - as shameful. In a climate where sexual purity became the primary marker of a superior Irish nation following Independence, especially when contrasted with the former colonizer, shame became a disciplining device and a means of establishing legitimate and illegitimate Irish subjects. ${ }^{46}$ Failed Irish subjects, that is "moral lapses," were symbolically but also physically excised from Irish nationhood through what I call gendered displacement - that is, the removal of transgressive women either through institutionalization or forced abortion travel to other jurisdictions, notably, overwhelmingly, the UK. ${ }^{47}$ The construction of women's bodies, sexuality, and relationships, as shameful has thus fundamentally informed social policies in Ireland and has underpinned the highly interventionist and often brutal practices by Church and State over the decades. Shame - a negative emotion that usually involves hiding a shameful moral failure, hence, gendered displacement - has long cut across public and private spheres to guarantee, through the excising of shameful gendered others and the strict regulation of women's bodies and social roles, a national identity centered on gendered, superior purity and virtue. The most intimate parts of women's lives were thus structured by an emotion that traversed public and private spheres to ensure the "public" governance of women based on their assumed "private" transgressions.

This was also true for the Irish abortion ban, which constructed women in need of abortion services as shameful and falling short of the ideals of Irish nationhood, with the criminalization of abortion itself often experienced as deeply shaming. ${ }^{48}$ Shame as an emotion that relates to our character, rather than our actions, and entails the assumption of a moral shortcoming that must be hidden from public view, is fundamentally concerned with invisibility. ${ }^{49}$ The threat of exposure of said shortcoming is usually obsessively avoided to avert irreparable damage to relationships following an altered perception of one's now tainted, moral character. Hiding and rendering invisible are thus an intrinsic part of the shame experience. However, over the many years that the Irish state, together with the Church, constructed women in need of abortion services as shameful, women have resisted such shaming.

\footnotetext{
${ }^{46}$ Fischer, "Gender, Nation, and the Politics of Shame: Magdalen Laundries and the Institutionalisation of Feminine Transgression in Modern Ireland."

${ }^{47}$ Fischer, "Abortion and Reproduction in Ireland: Shame, Nation-Building, and the Affective Politics of Place."

${ }^{49}$ Dolezal, The Body and Shame: Phenomenology, Feminism, and the Socially Shaped Body.
} 
More recently, and especially during the months leading to the referendum, such resistance was increasingly widespread, frequent, and, importantly, public. Rather than submitting to being cast as shameful, transgressive moral failures, women have reconfigured the prohibition on abortion and the dire consequences of this for themselves and their families, as shameful. ${ }^{50}$ Public policy, and thereby the state itself, were to be viewed as shameful, as its withholding of reproductive rights heartlessly and callously condemned women to innumerable harms, including physical and psychological injury, and even death. This deflection of shame from women needing abortion services and onto the state, and abortion policy in particular, operated through the rejection of shame's intrinsic mechanism of hiding. Rather than rendering women and their reproductive lives invisible and thereby shameful, a continuous and growing stream of women's testimony made the harms of the $8^{\text {th }}$ Amendment visible, thereby effectively countering the fear of exposure typical of the shame experience. The message was clear: women who had been traumatized by the abortion ban had nothing to be ashamed of, while the injuries revealed by their testimony pointed to shameful failures by the state, and the now much less influential Church [hierarchy].

Women were thus airing their often devastating stories concerning the most intimate, and private parts of their lives in order to redress public policy failures. Such stories underpinned the campaign's argument for women's need for privacy concerning reproductive matters, and aptly illustrated the harms inflicted by the state's infringement of women's private decision-making. For instance, women, sometimes supported by their partners, publicly told stories of receiving fatal fetal diagnoses and having to travel outside the state to access services there, lest they be forced to carry pregnancies to full term in Ireland. The advocacy group, Terminations for Medical Reasons (TFMR), especially, highlighted such cases and pointed to the failures in the Irish system, which denied them the reproductive healthcare they needed and thereby further traumatized them. Few people could fail to be moved at reports of people being unable to attend cremations and receiving the remains of their pregnancies by courier from clinics in the U.K. ${ }^{51}$ Their stories drew attention to a cruel and arbitrary legal regime that disregarded the suffering it inflicted on women and their families.

Other stories told in the media, at public meetings, and during canvasses, included accounts of pregnant women being denied medical treatment that would have been standardly provided elsewhere, and that ended up posing a significant threat not just to their health, but also their lives. ${ }^{52}$ Campaigners also related the stories of some of the other deaths resulting from such forced non-intervention, notably the case of Michelle Harte, who was diagnosed with cancer, but was denied a termination by Cork University Hospital's ethics board, and instead had to travel to the U.K. to

\footnotetext{
${ }^{50}$ See also Lisa Smyth, "Ireland's Abortion Ban: Honour, Shame, and the Possibility of a Moral Revolution," in The Abortion Papers Ireland: Volume 2, ed. Aideen Quilty, Sinead Kennedy, and Catherine Conlon (Cork: Cork University Press, 2015), 167-78.

${ }^{51}$ Sarah Bardon, "Stop Abandoning Pregnant Women, Say Parents of Baby Who Died at Birth," The Irish Times, March 22, 2018.

52 Kate Campbell, "'I Needed Surgery but Because I Was Pregnant, I Was Left to Rot," The Irish Times, May 19, 2018, https:/www.irishtimes.com/life-and-style/health-family/i-needed-surgery-butbecause-i-was-pregnant-i-was-left-to-rot-1.3500349.
} 
access an abortion, causing considerable delay and interruption to her cancer treatment. $^{53}$

Although women in Ireland had, for several years, increasingly revealed their experiences of crisis pregnancies or pregnancies turned into crises, and the devastating effects the $8^{\text {th }}$ Amendment had on them in such circumstances, the intense urgency of the months leading into the May referendum resulted in an explosion of women's testimonies. The In Her Shoes: Women of the Eighth Facebook page provided an invaluable platform in this regard, as it allowed women to air their stories anonymously. It could barely keep up with the volume of material, and is today still posting women's accounts. ${ }^{54}$ Such stories, told by people who were abandoned by the Irish state in times of crisis - be it in the wake of a fatal fetal diagnosis, ${ }^{55}$ miscarriage, ${ }^{56}$ rape,${ }^{57}$ cancer,${ }^{58}$ or other physical and mental anguish,${ }^{59}$ including "simply" being overwhelmed with a pregnancy at a particular moment in time ${ }^{60}$ were deeply moving and had a major effect on the eventual outcome of the vote. ${ }^{61}$

This can be attributed to the fact that women's testimonies vividly described and clearly set out the harms the $8^{\text {th }}$ Amendment was inflicting. Added to this, the often heart-wrenching, emotive nature of these stories in and of itself supported the argument for the need to protect women's privacy regarding reproductive matters. The very fact that women were now seemingly forced to reveal their "private" hurt in

${ }^{53}$ Barry Roche, "Mother Might Still Be Alive but for Eighth Amendment - Gynaecologist," The Irish Times, May 13, 2018, https://www.irishtimes.com/news/ireland/irish-news/mother-might-still-be-alivebut-for-eighth-amendment-gynaecologist-1.3493958.

${ }^{54}$ Anonymous, "Anonymous," In Her Shoes: Women of the 8th, September 22, 2018, https://www.facebook.com/InHerIrishShoes/posts/239134833427608:0? tn_ =K-R.

${ }_{5}$ Amy Walsh, "My Daughter Was Dying inside Me. I Could Not Save Her,"” The Irish Times, July 1, 2017, https:/www.irishtimes.com/life-and-style/people/my-daughter-was-dying-inside-me-i-could-notsave-her-1.3137930.

${ }^{56}$ Kitty Holland, "Savita Halappanavar's Father Urges Yes Vote in Abortion Referendum," The Irish Times, April 11, 2018, https://www.irishtimes.com/news/social-affairs/savita-halappanavar-s-fatherurges-yes-vote-in-abortion-referendum-1.3457368?mode=sample\&auth-failed=1\&pw-

origin=https $\% 3 \mathrm{~A} \% 2 \mathrm{~F} \% 2 \mathrm{Fwww}$.irishtimes.com $\% 2 \mathrm{Fnews} \% 2 \mathrm{Fsocial}$-affairs $\% 2 \mathrm{Fsavita}$-halappanavar-sfather-urges-y.

57 Anonymous, In Her Shoes: Women of the 8th, April 24, 2018, https:/www.facebook.com/InHerIrishShoes/posts/161104667897292. This Facebook page played a vital role in allowing women to share their stories anonymously, thereby highlighting the countless hardships bread by the $8^{\text {th }}$ Amendment.

${ }^{58}$ Roche, "Mother Might Still Be Alive but for Eighth Amendment - Gynaecologist."

${ }^{59}$ Campbell, “'I Needed Surgery but Because I Was Pregnant, I Was Left to Rot."”

${ }^{60}$ It is important not to set up certain abortions as more virtuous than others, hence my reference to "simply" having a pregnancy in the wrong situation, at the wrong time. This is also expressed by one of the people sharing her story on the In Her Shoes Facebook page, who says "I had "the worst" type of abortion. It was not for FFA [Fatal Fetal Abnormality], Rape or Incest. My termination was the one people seem to be most uncomfortable about. I chose not to be pregnant." Anonymous b,

"Anonymous," In Her Shoes: Women of the 8th, April 26, 2018, https://www.facebook.com/InHerIrishShoes/photos/a.142348133106279.1073741828.1422431097834 48/159549638052795/?type=3\&theater.

${ }^{61}$ According to an exit poll commissioned by the public broadcaster, and conducted on the day of the vote with a sample of 3,779 eligible voters, $43 \%$ of respondents noted people's personal stories covered in the media as an influencing factor in their decision on to how to vote. Moreover, the experiences of people they knew were an influencing factor for 34\% of respondents. Taken together, then, the stories of people directly affected - shared either in the media or through personal telling played a significant role in voters' decision-making - see McShane, "Thirty-Sixth Amendment to the Constitution Exit Poll, 25th May, 2018." 
public by sharing stories about the most intimate parts of their lives - covering not just their pregnancies, but also experiences of miscarriage, sexual violence, and a host of emotionally challenging topics - to highlight the inadequacy of the state's laws on abortion seemed to constitute a second-order level of harm all by itself. How could the state, for decades, stand over a legal regime that so traumatized and damaged women and their families? And how was it just, or compassionate, or fair to place the burden for changing this regime on women by making them reveal their "private" hurt publicly in order to transform the flawed public policy that inflicted such hurt in the first place $?^{62}$ Indeed, as one commentator recently put it, "part of the cruelty of the recent referendum campaign was how women and couples had to give up their anonymity and explain in detail the traumas imposed by our [Ireland's] hypocrisy." ${ }^{\prime 3}$

A second aspect of the affectivity of campaign efforts to repeal, was thus not just the rejection of the historic mobilization of shame and its deflection onto the state, with its attendant move from shameful invisibility to de-shaming visibility, but also the simultaneous rendering visible of private trauma. Indeed, in order to resist the Church-State sponsored injunction to hide as shameful gendered others, women harmed by the abortion ban were forced, at the same time, to reveal private hurt, grief, and loss. Just as shame thus cut across public and private spheres, so these emotions of trauma, through their deliberate exposure to resist shame, took on public, political significance. In other words, in a bid to bring about political change in the public sphere and to reject their construction as shameful by Church and state, women deployed exposure as a typical means of countering shame, which entailed affective exposure of previously private trauma, and the revealing of feelings of grief, hurt, and loss.

For, trauma, and attendant, negative feelings of grief and pain, are emotions we usually want to hide from others, to experience away from the public glare when we know ourselves to be at our most vulnerable. The public revealing of such vulnerability through women's testimony influenced people's voting behavior by showing them the deep traumas the $8^{\text {th }}$ Amendment inflicted. Indeed, members of the public were implicitly called upon to feel this pain, to empathize, and to respond emotionally, that is, to redress the hurt caused by Ireland's abortion regime with its affective counterpart. Several referendum posters thus appealed for a 'yes' vote on the basis of the need for "compassion" (Figs. 4 \& 5), and Together for Yes campaign literature referenced the need to "regulate abortion and care for the women who need it" (Fig. 2). Voting 'yes' thus meant undoing the traumas inflicted by Ireland's abortion laws by bringing about a more caring and compassionate policy that supports women in times of crisis. As such, the vote became a measure of the love people have for the women in their lives, and by extension the love a callous, uncaring state should now exhibit toward women - as the campaign literature noted: "a woman you love could need your Yes" (see Fig. 2).

\section{Affective Vulnerability, Exposure, and the Public/Private Dichotomy}

\footnotetext{
${ }^{62}$ That is not to say that there can't also possibly be a cathartic aspect to sharing traumatic experiences. However, the point is rather that such catharsis should be freely chosen, rather than "forced" by unjust policies.

${ }^{63}$ Mark Murphy, "Ireland's New Abortion Service Is the Envy of Many Healthcare Systems," The Irish Times, 2019.
} 
What can the latter dimension of the affectivity attached to abortion activism - the revealing of private trauma and its attendant emotions - tell us about the role of emotion and the public/private dichotomy in feminist campaigning and feminist theoretical work? How might it inform feminist conceptualizations of vulnerability and resistance in feminist theory? Most obviously, women's exposure of "private" trauma and its attendant emotions in order to redress shaming, harmful public policies shows that there are costs associated with doing feminist work, that campaigning can render one materially - owing to retaliatory attacks on one's body or bodily wellbeing, including one's ability to provide for oneself - but also emotionally vulnerable. Resisting state-sponsored shaming through affective exposure thus entails a transgressing of one's privacy, the revealing of traumatic emotions one would rather keep to oneself, and risks further traumatization, should such vulnerability be exploited. However, as Butler shows, vulnerability need not be equated with injurability, but may simply indicate a facet of the human condition. Indeed, Judith Butler's well-known theorization of vulnerability as embodied phenomenon that structures our materiality and how we live together in openness toward each other, may be instructive in this context. Butler notes that the body is "a social phenomenon: it is exposed to others, vulnerable by definition." ${ }_{64}^{4}$ Although Butler does not explore the affective dimension of such bodily exposure, we may postulate, purely by way of observation of our affective embodied ontology, that we are similarly affectively exposed to each other.

Do we have a claim, then, to "private" emotions and privacy concerning trauma? I'd like to offer the view that the demarcation of public and private spheres may be set precisely to regulate how, how much, and in which ways one is affectively exposed and forced to reveal trauma. Certainly, such regulation may be infringed, for instance through the insensitive handling or leaking of private information and data, but generally, we believe that there are limits to what one is obliged to reveal in public and that there is such a thing as private information in the first place. Feelings of hurt, loss, grief, arising from trauma, although sometimes expressed in the public sphere, are often deemed to be of a private nature, to be experienced within the confines of the private sphere. Returning to Butler's definition of vulnerability, then, it is possible to say that although we are materially and affectively exposed to each other, we do not take such exposure to be complete, occurring at any time and in any setting. The very purpose of drawing the line between public and private seems to be to set parameters, to protect us from constant exposure and to manage the material and affective vulnerability this constitutes. While one of the intrinsic features of vulnerability is also the possibility of injury, and in the case of affective vulnerability further psychic injury, I maintain that exposure of trauma and one's attendant emotions may, in itself form a harm when this transgresses one's desired parameters set by the private sphere.

On the other hand, I do not wish to deny the agency of abortion activists and their choice to reveal their stories. Indeed, it is important to reiterate that affective vulnerability - in the sense of one's exposure to others, managed through the public/private distinction - may be used as an important campaigning tool and as a means of resistance. Indeed, as elaborated above, revealing and exposure act as a counter to the hiding and invisibility of shame and shaming state policies. Again, we

\footnotetext{
${ }^{64}$ Judith Butler, Frames of War: When Is Life Grievable? (London: Verso, 2016), 33.
} 
can supplement Butler's insights on embodied nonviolent resistance with a focus on the affective dimension this might entail. Butler notes that "in the moment of actively appearing on the street, we are exposed, vulnerable to injury of one kind or another." 65 Similarly, we can say that affective exposure in the public sphere leaves one open to injury and further harm. And yet, Butler understands exposure in terms of the potential for political action. She writes, "resistance requires exposing the abandoned or unsupported dimensions of life, but also mobilizing that vulnerability as a deliberate and active form of political resistance, an exposure of the body to power in the plural action of resistance." ${ }^{\prime 66}$ Much the same can be said of activists' exposure of bodily and psychic trauma and the grief and hurt this entails, as it requires the visibility of what we might term the psychically "unsupported dimensions of life," while at the same time reconfiguring affective vulnerability as a deliberate political refusal, an "active form of political resistance." ${ }^{67}$ The deliberate transgression of privacy and one's exposure, can, therefore, constitute a form of political resistance that involves the mobilization of emotions borne from trauma to effect change in the public sphere.

\section{Emotion and the Redrawing of Public and Private}

In sum, it may be said that campaigning around the Irish abortion referendum is instructive for how feminists might engage with the ongoing controversy surrounding the public/private divide, and for how we think about emotions in this context. Although feminists are rightly suspicious of the public/private distinction and the historic uses it has been put to, the Irish context shows that arguments about what should be public and private, about where, exactly, the line should be drawn, can be beneficially employed by feminists seeking political change. Campaigners managed to present the Irish abortion ban as an undue interference by the state in women's private decision-making concerning their bodies and reproductive healthcare. While the case for the need to protect privacy is long-standing in international human rights law, the Irish case shows that such arguments may be translated into grassroots campaigning and activism in ways that resonate with members of the public. Notably, the testimonies of women injured by the $8^{\text {th }}$ Amendment made the abstract concepts of 'public' and 'private' tangible. They did so by showing the inordinate influence the state exercised by denying women with crisis pregnancies healthcare and imposing treatment - or lack of treatment - against women's wishes and denial of their decision-making and agency. Moreover, women's testimony also gave substance to the idea of the need for privacy through affective exposure, as women revealed what one would rather keep hidden from public glare, and "private" traumas and their attendant feelings were widely aired. While such exposure, which counters shame in as far as shame relies on invisibility, may render feminist activists subject to further injury, it is important to note our general openness to each other as a feature of what, following Butler, I have termed affective vulnerability. As I have argued, such vulnerability is informed by what we establish as public and private, and therefore can be negotiated by feminists seeking to redraw the line between both spheres to achieve feminist, political ends.

\footnotetext{
${ }^{65}$ Judith Butler, Notes Toward a Performative Theory of Assembly (Cambridge, Mass.: Harvard University Press, 2015), 184.

${ }^{66}$ Judith Butler, Notes Toward a Performative Theory of Assembly (Cambridge, Mass.: Harvard University Press, 2015), 184.

${ }^{67}$ Judith Butler, Notes Toward a Performative Theory of Assembly (Cambridge, Mass.: Harvard University Press, 2015), 184.
} 
With that said, we should proceed with caution when entering debates on public/private and the role of emotion in feminist campaigning, as the mobilization of emotion requires careful analysis in terms of how people are presented and to what political ends such presentation is put. For instance, one could argue that the Together for Yes polling and market research that determined "compassion", "support", or "care" as more persuasive terms for undecided voters unduly influenced formal campaign strategizing and reinforced a view of women as victims in need of protection, rather than as rights-holders or agents. Did it result in conceptualizations of women to be pitied rather than empowered? And if so, did this mean that the campaign was feeding into what sociologist Kathleen Lynch has identified as an Irish tendency to base policies on charity rather than on principles of social justice? ${ }^{68}$ This is certainly one possible reading of Together for Yes, and remains contentious among feminists. For instance, feminist legal scholar and activist, Máiréad Enright has written about her worries that "Together for Yes's core campaign messages were out of sync...Its emphasis on women less as political agents than as vulnerable recipients of love, compassion and decent medical care of course marked a departure from the cruelties of the abortion ban. But I desperately missed the more assertive message of the earlier Repeal movement, with its unashamed emphasis on bodily autonomy." 69

This also raises the related question of which emotions feminists utilize, and which are side-lined or repressed. In the Irish case, love, compassion, and care, were promoted by the Together for Yes campaign body. While I've already outlined that these "positive" emotions were asked for in the context of a public revealing of the damage the $8^{\text {th }}$ Amendment had long inflicted on women and their families, and that such revealing acted as a means of countering shaming, the emotion of shame remained surprisingly unarticulated in the months leading to the referendum, certainly in the official literature. There were exceptions to this, notably a poster by the socialist, pro-choice group ROSA, which read "Stop shaming women! Vote yes." Generally, though, the message of love was not tied to the long-standing mobilisation of shame against women in Ireland, and the reconfiguration of women in need of abortion services from shameful others to women subject to injury by the Irish state, was not always explicitly framed in terms of the language of shame.

Finally, I wish to reiterate emotion's role in driving political resistance. Affective vulnerability, and the exposure we affectively have towards each other, can be powerfully drawn on as a deliberate political act that allows "private" traumas and attendant feelings to traverse public and private spheres in order to bring about policy change.

Unfortunately, as such exposure carries the risk of further injurability, and public exposure in and of itself may be experienced as an infringement, there are costs associated to utilising affective exposure as a political tool, especially as this comes in the wake of existing injury and harm inflicted by the state. Whether, how much, and to what extent, we engage, as feminists, in such exposure, and the changes in public and private this entails for us personally, should be negotiated by each of us, with the support of our communities, to minimise harm and promote, as far as possible, self-care, as we continue to redraw the line between public and private to bring about feminist, political change.

\footnotetext{
${ }^{68}$ Kathleen Lynch, "EQUALITY AS RHETORIC: THE CARELESS STATE OF IRELAND,” McGill Summer School, 2013, http:/www.macgillsummerschool.com/equality-as-rhetoric-the-careless-stateof-ireland/.

${ }^{69}$ Máiréad Enright, “"The Enemy of the Good': Reflections on Ireland's New Abortion Legislation,"

Feminists@law8,no.2(2018).P.8
} 


\section{REFERENCES}

Amnesty International. "She Is Not a Criminal: The Impact of Ireland's Abortion Law," 2015.

http://www.amnestyusa.org/pdfs/Ireland_She_Is_Not_A_Criminal.pdf.

Anonymous. "Anonymous." In Her Shoes: Women of the 8th, September 22, 2018. https://www.facebook.com/InHerIrishShoes/posts/239134833427608:0?_tn__= K-R.

Anonymous a. "Anonymous." In Her Shoes: Women of the 8th, April 24, 2018. https://www.facebook.com/InHerIrishShoes/posts/161104667897292.

Anonymous b. "Anonymous." In Her Shoes: Women of the 8th, April 26, 2018. https://www.facebook.com/InHerIrishShoes/photos/a.142348133106279.107374 $1828.142243109783448 / 159549638052795 /$ ?type $=3 \&$ theater.

Bacik, Ivana. "A Feminist Review of the Law on Abortion." In Irish Feminisms: Past, Present and Future, edited by Clara Fischer and Mary McAuliffe, 147-68. Dublin: Arlen House/Syracuse University Press, 2015.

Bardon, Sarah. "Stop Abandoning Pregnant Women, Say Parents of Baby Who Died at Birth." The Irish Times, March 22, 2018.

Barry, Ursula. "What Do We Mean by Bodily Autonomy? And What Does Bodily Autonomy Mean for Women in Particular?" In Autonomy, 180-92. Cork: New Binary Press, 2018.

Butler, Judith. Frames of War: When Is Life Grievable? London: Verso, 2016.

- Notes Toward a Performative Theory of Assembly. Cambridge, Mass.: Harvard University Press, 2015.

Campbell, Kate. "'I Needed Surgery but Because I Was Pregnant, I Was Left to Rot." The Irish Times, May 19, 2018. https://www.irishtimes.com/life-andstyle/health-family/i-needed-surgery-but-because-i-was-pregnant-i-was-left-torot-1.3500349.

"Commission of Investigation (Mother and Baby Homes and Certain Related Matters)." Dublin, 2015.

http://www.dcya.gov.ie/documents/Mother_and_Baby_Homes/20150109DraftOr derCommofInvestigation.pdf.

Constitution of Ireland - Bunreacht na hÉireann, (2015).

D’Arcy, Kathy, ed. Autonomy. Cork: New Binary Press, 2018.

De Londras, Fiona, and Máiréad Enright. Repealing the 8th: Reforming Irish Abortion Law. Bristol: Policy Press, 2018.

Dolezal, Luna. The Body and Shame: Phenomenology, Feminism, and the Socially Shaped Body. London: Lexington Books, 2015.

Enright, Máiréad. “'No. I Won't Go Back': National Time, Trauma and Legacies of Symphysiotomy in Ireland." In Law and Time, edited by Sian Beynon-Jones and Emily Grabham. Routledge, 2018.

_. "The Enemy of the Good': Reflections on Ireland's New Abortion Legislation.”Feminists@law 8,no. 2 (2018).

Fegan, Joyce. "Donegal the Only Constituency to Vote No." The Irish Examiner, May $28,2018$.

Fischer, Clara. "Abortion and Reproduction in Ireland: Shame, Nation-Building, and 
the Affective Politics of Place.” Feminist Review 122, no. 1 (2019).

. "Feminist Philosophy, Pragmatism, and the 'Turn to Affect': A Genealogical Critique." Hypatia: A Journal of Feminist Philosophy 31, no. 4 (2016): 810-26.

- "Gender, Nation, and the Politics of Shame: Magdalen Laundries and the Institutionalisation of Feminine Transgression in Modern Ireland." Signs: Journal of Women in Culture and Society 41, no. 4 (2016): 821-43.

- ed. "Gender and the Politics of Shame." Hypatia: A Journal of Feminist Philosophy [Special Issue] 33, no. 3 (2018).

_. "Revealing Ireland's 'Proper' Heart: Apology, Shame, Nation." Hypatia: A Journal of Feminist Philosophy 32, no. 4 (2017): 751-67.

Fraser, Nancy. Justice Interruptus: Critical Reflections on the "Postsocialist" Condition. London: Routledge, 1997.

Government of Ireland. "General Scheme Of A Bill to Regulate Termination of Pregnancy," March 28, 2018. https://health.gov.ie/wpcontent/uploads/2018/03/General-Scheme-for-Publication.pdf.

Health Service Executive. "National Consent Policy," 2013.

Holland, Kitty. "How the Death of Savita Halappanavar Revolutionised Ireland." The Irish Times, May 28, 2018.

. "Mixed Race Irish: 'We Were the Dust to Be Swept Away." The Irish Times, July 18, 2015.

- "Savita Halappanavar's Father Urges Yes Vote in Abortion Referendum."

The Irish Times, April 11, 2018. https://www.irishtimes.com/news/social-

affairs/savita-halappanavar-s-father-urges-yes-vote-in-abortion-referendum-

1.3457368 ? mode $=$ sample \&auth-failed $=1 \&$ pw-

origin $=$ https $\% 3 \mathrm{~A} \% 2 \mathrm{~F} \% 2 \mathrm{Fwww}$.irishtimes.com $\% 2$ Fnews $\% 2$ Fsocial-

affairs\%2Fsavita-halappanavar-s-father-urges-y.

Lynch, Kathleen. "EQUALITY AS RHETORIC: THE CARELESS STATE OF

IRELAND." McGill Summer School, 2013.

$\mathrm{http}: / / \mathrm{www} . \mathrm{macgillsummerschool.com/equality-as-rhetoric-the-careless-state-of-}$ ireland/.

McQuinn, Cormac. “'Together For Yes' Group Deny 'No' Campaigners Have Stolen a March in Poster War." The Irish Independent, 2018.

McShane, Ian. "Thirty-Sixth Amendment to the Constitution Exit Poll, 25th May, 2018," 2018. https://static.rasset.ie/documents/news/2018/05/rte-exit-poll-final$11 \mathrm{pm} . \mathrm{pdf}$.

Murphy, Mark. "Ireland's New Abortion Service Is the Envy of Many Healthcare Systems." The Irish Times, 2019.

O'Sullivan, Eoin, and Ian O'Donnell. "Explaining Coercive Confinement: Why Was the Past Such a Different Place?" In Coercive Confinement in Ireland, edited by Eoin O'Sullivan and Ian O’Donnell, 250-94. Manchester: Manchester University Press, 2012.

Okin, Susan Moller. Justice, Gender and the Family. New York: Basic Books, 1989.

Pateman, Carole. The Disorder of Women: Democracy, Feminism, and Political Theory. Stanford: Stanford University Press, 1989.

- The Sexual Contract. Cambridge: Polity Press, 1988.

Protection of Life During Pregnancy Act 2013, 2013. http://www.irishstatutebook.ie/eli/2013/act/35/enacted/en/pdf.

Roche, Barry. "Mother Might Still Be Alive but for Eighth Amendment Gynaecologist." The Irish Times, May 13, 2018.

https://www.irishtimes.com/news/ireland/irish-news/mother-might-still-be-alive- 
but-for-eighth-amendment-gynaecologist-1.3493958.

RTÉ. “Referendum 2018.” RTÉ News, 2018. https://www.rte.ie/news/eighthamendment/results/.

Smyth, Lisa. Abortion and Nation. New York: Routledge, 2005.

. "Ireland's Abortion Ban: Honour, Shame, and the Possibility of a Moral Revolution." In The Abortion Papers Ireland: Volume 2, edited by Aideen Quilty, Sinead Kennedy, and Catherine Conlon, 167-78. Cork: Cork University Press, 2015.

Walsh, Amy. "My Daughter Was Dying inside Me. I Could Not Save Her." The Irish Times, July 1, 2017. https://www.irishtimes.com/life-and-style/people/mydaughter-was-dying-inside-me-i-could-not-save-her-1.3137930. 


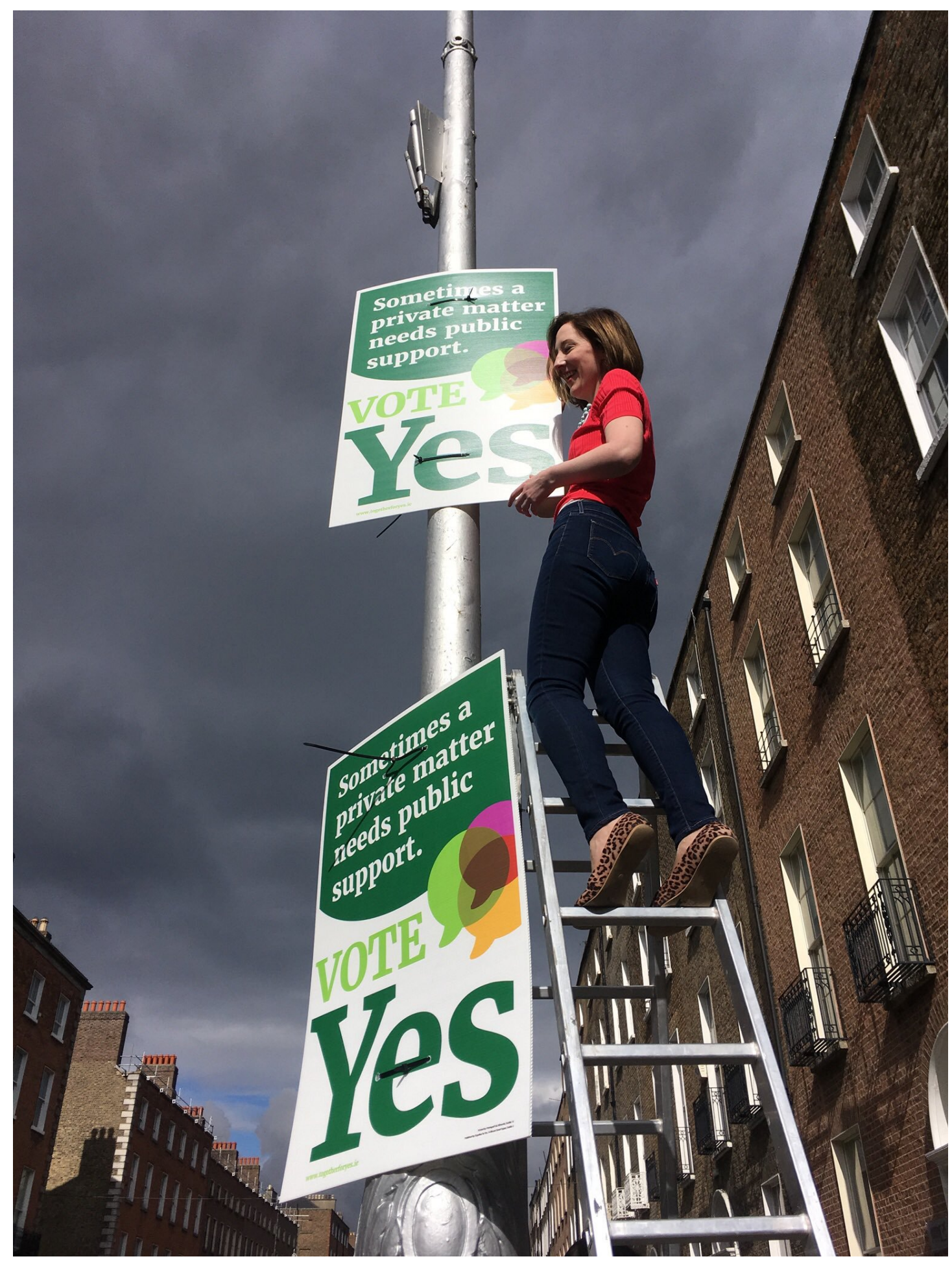

Figure 1: Together for Yes posters launched. 


\section{VOTE

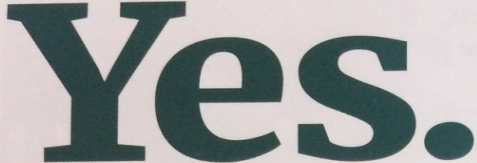

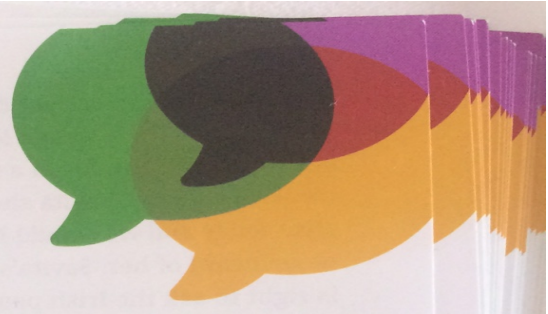

A woman you love could need your Yes.

Abortion is already a reality in Ireland. On $25^{\text {th }}$ May your YES vote will mean we can regulate abortion and care for the women who need it.

We know that pregnancy can

sometimes go wrong.

Vote YES to allow doctors to treat women whose health is put at risk in pregnancy.

Every day at least two women

take an abortion pill at home alone with no medical support. Most are already mothers.

Vote YES to ensure women who need an abortion will have the support of their doctor.

Life is complicated, and every pregnancy is different.

Vote YES to allow a woman to make important decisions about her own life and family.

Voting NO means forcing women and couples with a diagnosis of fatal foetal

anomaly, or rape victims

who become pregnant, to

travel abroad for care.
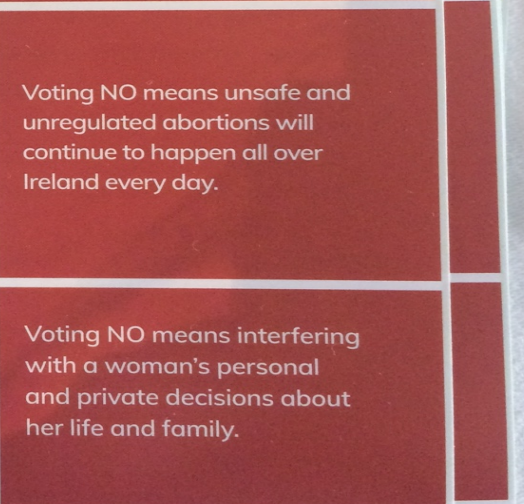

Have more questions? Visit www.togetherforyes.ie

Figure 2: Together for Yes leaflet. 


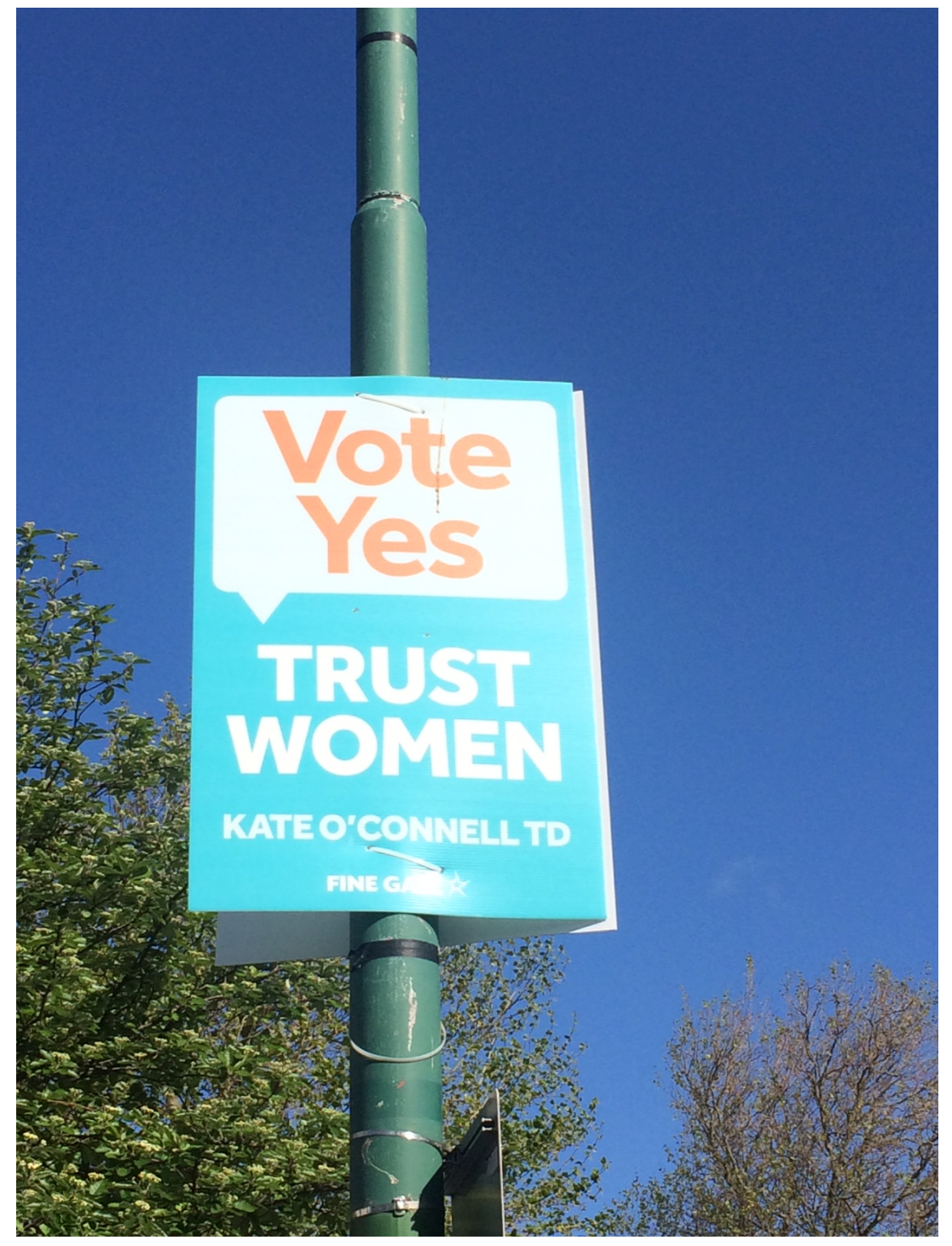

Figure 3: Campaign poster by public representative, Kate O’Connell. 


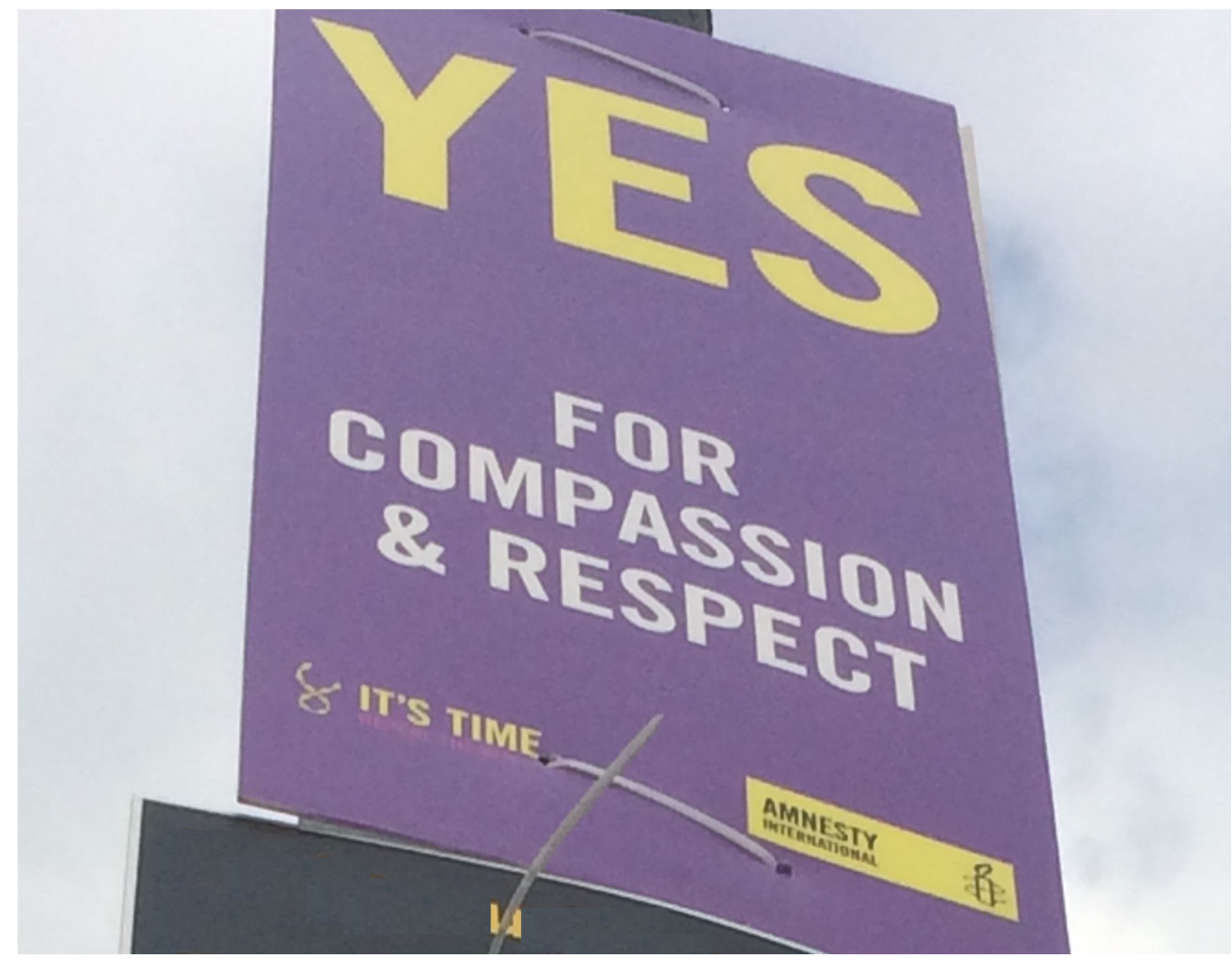

Figure 4: Campaign poster by Amnesty International.

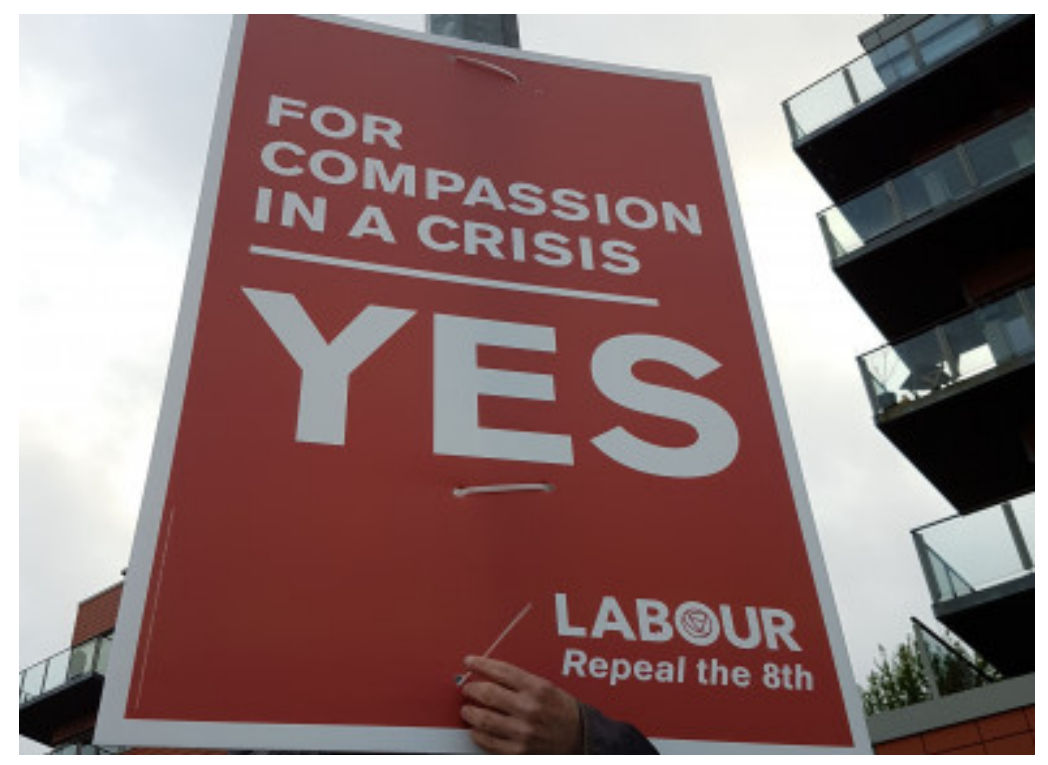

Figure 5: Campaign poster by the Irish Labor Party. 


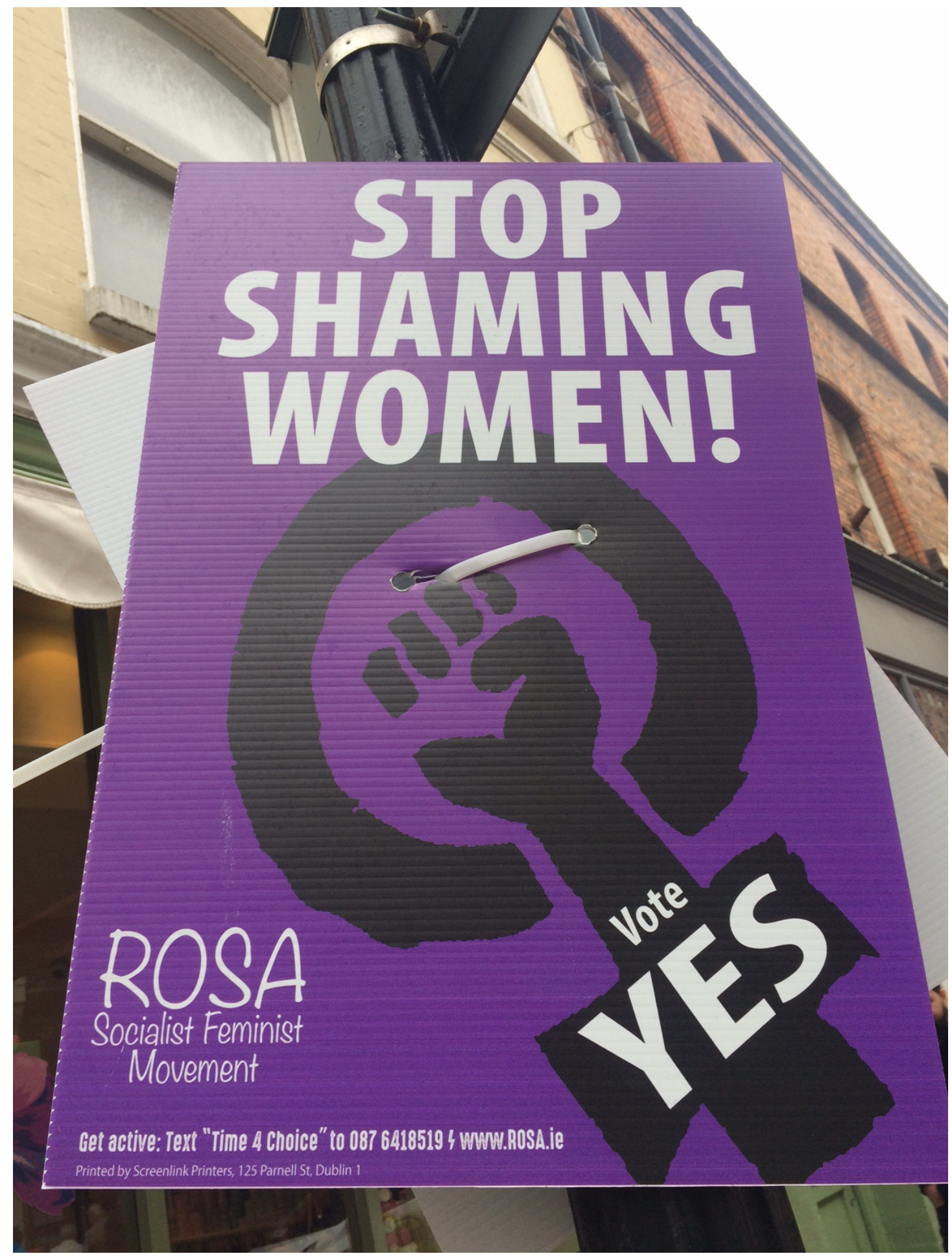

Figure 6: Campaign Poster by ROSA. 